\title{
An Empirical Study on Xenophobia in Almeria (Spain)
}

\author{
by Gonzalo Herranz de Rafael \\ University of Almería
}

Sociological Research Online, 17 (2) 3 $<$ http://www.socresonline.org.uk/17/2/3.html> $10.5153 /$ sro. 2623

Received: 25 Nov 2011 Accepted: 27 Feb 2012 Published: 31 May 2012

\begin{abstract}
This article examines the existence of xenophobia in ten census tracts, each with the greatest and lowest density of immigration in the city of Almeria. The study shows that immigration density encourages xenophobic attitudes and behaviours within the population, as well as segmentation according to the immigrant's place of origin. This paper presents a descriptive and explanatory analysis of xenophobia. The descriptive analysis profiles the most and least xenophobic areas in Almeria. The explanatory analysis uses five models of Pearson's correlations for socio-demographic variables and attitudes toward immigration (independent variables) and the xenophobia index (dependent variable) to test which variables best explain the level of xenophobia in Almeria. It was found that the cognitive level or beliefs about specific aspects of immigration have a high degree of explanatory power in addressing variation in the degree of xenophobia.
\end{abstract}

\section{Keywords: Xenophobia, Density, Segmented, Almeria}

\section{Introduction}

1.1 The purpose of this study is to measure xenophobia in the different census districts of Almeria (Spain). Previous studies concluded that the immigration density was a key indicator in explaining xenophobia (Herranz, 2008, 2008a, 2010). We conducted two studies, one with a representative sample of municipalities and another with a representative sample of the census districts of municipalities in the province of Almeria. We found that the xenophobia index was higher in municipalities with a high immigrant density and lower in census districts with high immigrant density. This difference is explained by the increased interaction and familiarity between immigrants and the native population, thereby leading to less xenophobic attitudes (Herranz, 2008, 2008a). Hence, we decided to conduct further research in a particular city (Almeria) with a high rate of immigration and compare only the ten neighborhoods with the greatest density of immigrants to the ten that have the lowest density of immigrants.

1.2 We begin with the idea that the analysis of xenophobia should be segmented on the basis of immigration density because sample population surveys reflect opinions and attitudes toward immigration that are unrealistic, by assigning equal weight to people living in areas with $20.99 \%$ foreigners, such as Almería, and people living in areas where foreigners make up less than $4 \%$ of the population, such as Lugo (according to the Municipal Census of January 2009). Moreover, most of the cited Spanish population polls reflect positive attitudes toward immigration (e.g. Cea D'Ancona 2002; Diez 2005, Herranz 2010; Pérez \& Desrues 2007) a fact that is not consistent with the results of other studies, both quantitative (as in our case) and qualitative, in which a greater segmentation of the population based on the density of immigrants was taken into account. For some neighbourhoods with high immigrant density above $15 \%$ of the total population- Gonzalez found a general attitude, widespread and deep, of rejection toward cohabitation with immigrants. This was expressed as a feeling of having been "invaded" and translates into an overall negative opinion on immigration in Spain (Gonzalez, 2004). Cea also shows how "xenophobia (declared in the surveys) is spreading in Spain, just as in the group of European Union countries, as immigration pressure increases from non-EU countries. More so when the immigrants are Arabs" (2004: 205).

1.3 Therefore, the aim of this study is to see whether xenophobia is primarily determined by the density of immigrants. The analysis includes ten census district of high immigrant density in the city of Almería and ten of low immigrant density. In short, this study can help us establish urban design policies that take into account the dispersion of the immigrant population in order to prevent possible outbreaks of xenophobia in highly segregated environments 


\section{Theoretical Background}

2.1 Before we begin analyzing the data, it is important to define what is meant by xenophobia and distinguish it from another concept that has often been used as a synonym: racism. As has already been indicated elsewhere (see Herranz, 2002, 2008, 2008a, 2010), xenophobia refers to attitudes or behaviours developed by a social or ethnic group (in the latter case, the term ethnophobia is also used) based on fear or caution concerning other groups (ethnic, social or national) that are considered foreign ${ }^{[1]}$. Etymologically, the term derives from two Greek words: xeno, meaning foreigner or guest, and phobia, meaning fear of or caution towards.

2.2 More specifically, xenophobia can be defined as the rejection or exclusion of foreigners because of ignorance and fear as dramatized in hate and hostility toward them. Empirically, xenophobia occurs during localized multicultural interactions. Xenophobic attitudes and behavior are closely related to ethnocentrism-people overestimate their own culture, nationality, race or ethnic group, over all others. However, no one, in principle, is considered xenophobic until the conditions are favorable for expressing xenophobia. One such condition occurs when, in a short time and in a certain area, the density of foreign immigrant population is considerably increased.

2.3 That's one of the findings observed in most of the research carried out on immigration and xenophobic attitudes in Spain (see, among others, Cea D'Ancona, 2002, 2005, 2009, Cea D'Ancona and Vallés, 2008, OPAM 2009; Rinken et al., 2009, Calvo 2000, Ministerio de Trabajo e Inmigración, 2008, Ten, 1998, 2005, 2009, Gimeno, 2001; Escandell and Cebeaunu 2009; Aguinaga, 2006). This circumstance occurs with greater emphasis when people feel a fear of the loss of national-cultural identity (Baker, 1981; Van Dijk, 1987, Sniderman et al., 2004) or the decline of socio-economic status (Blumer, 1958; Quilliam, 1995; Hargreaves and Leaman, 1995, Solé et al., 2000.2001, 1995), or even the fear of the spread of ethnic miscegenation and acculturation (Leong, 2008).

2.4 The concept of density can be approached from two perspectives: a demographic perspective that measures the number of immigrants and their distribution/concentration in space; and a sociological perspective that is dominant in studies of the effects of immigration that attempt to analyse the number of immigrants in a given population according to their place of origin and their process of segmented incorporation [2].

2.5 In the sociological tradition, it was Durkheim's work, The Division of Labor (1893), and Wirth's article, Urbanism as a way of life (Wirth 1938), which first used the concept of moral density and population density. Durkheim established the idea that moral and population densities are related to the division of labor, resulting in greater contact between individuals. As a result, they achieve greater solidarity, mutual dependence, and cooperation.

2.6 In our case, the density, defined as the number of immigrants in a given population according to their place of origin and segmental incorporation process, does not lead to greater cooperation and dependence, but a greater tendency within the native population to develop xenophobic attitudes and behaviors. From our point of view, it is not only is the number of immigrants and their distribution and concentration in a society that is important, but also their origin (nationality, ethnicity or race) and their concentration in a given area.

2.7 The concept of density is associated with the number of immigrants residing in a given habitat in proportion to its population. In this sense, it is expected that xenophobia, in terms of attitudes and behaviour, will be greater in census districts where a greater numbers of immigrants live and less intense in those where the number of immigrants is lower.

2.8 Density, together with other intervening factors ${ }^{[3]}$ such as an exponential growth in the number of immigrants in a short period of time (which renders insufficient the period of internalisation and adaptation to new conditions that facilitates inter-ethnic coexistence), further facilitates xenophobic attitudes and behaviours. Its scope, however, will differ from one ethno-cultural group to the next; as noted above, not all nationalities encounter the same acceptance or rejection by the native population.

2.9 Also, xenophobic attitudes and behaviors will vary depending on demographic and socio-political profile of subjects, their positions towards immigration, and their assessments of the state's response.

2.10 Five regression models have been created to test the hypothesis. The first is based on the most significant socio-demographic and socioeconomic variables at play; the second is based on a range of attitudes toward immigration, like its impact on unemployment, wages and crime; the third is based on a range of sociopolitical-cultural variables; the fourth examines the situation for both regular and irregular immigrants, and the last considers in depth the thoughts or beliefs of the population of Almería with respect to certain immigration-related issues.

\section{Methods and data}

\section{Participants}

3.1 According to the Municipal Census of January 1,2008, the proportion of foreigners in the city of Almeria was 10\%; the total population was 187,521 inhabitants and the number of foreign citizens registered in the municipality was 18,742. If we compare the data with percentages for other provincial capitals, it emerges that Almería has a high density of immigrants and, as we shall see, that these immigrants are of nationalities most often rejected by the Spanish population.

3.2 Of the fifty provincial capitals, Almeria has the seventeenth highest proportion of registered foreigners. The ten provincial capitals with the highest proportion are: Castellón (20.17\%), Girona (19.69\%), Palma de Mallorca (19.49\%), Lleida (18.23\%), Barcelona (16.90\%), Madrid (16.79\%), Tarragona 
(16.54\%), Guadalajara (14.53\%), Alicante (14.44\%) and Valencia (14.15\%). The ten capitals with the fewest foreigners are Cádiz (1.32\%), Córdoba (2.33\%), Cáceres (2.53\%), Jaén (3.01\%), Palencia (3.70\%); Pontevedra (3.89), Badajoz (4.02\%), Ceuta (4.03\%), Zamora (4.08\%) and Seville (4.28\%). In general, the highest concentrations occur in the Catalan capitals, the eastern zone, and Madrid while the lowest are in inland areas and, especially, in Andalusia. Logically, we can conclude that not all capitals contain the same type of foreigners by nationality. For example, in Castellón, which is the capital with the most foreigners in Spain, only 24.24\% come from Africa or South America.

3.3 If we examine the nationality of foreign residents in the ten provincial capitals with the greatest number of foreigners, we observe that although Almería contains a smaller percentage, it has taken in the greatest number of foreigners of African origin and, in particular, of Moroccan origin (Moroccans comprise the largest African immigrant group in the ten capitals).

Table 1. Spanish provincial capitals and percentage of foreigners. Special reference to Africa and America.

\begin{tabular}{|c|c|c|c|c|c|c|c|}
\hline Capitals & $\begin{array}{l}\% \\
\text { Foreigners }\end{array}$ & $\begin{array}{l}\text { Total } \\
\text { foreigners }\end{array}$ & Population & Africa & Nationality $\%$ & America & Nationality $\%$ \\
\hline Almería & 10 & 18,742 & 187,521 & $\begin{array}{l}7,345 \\
(\mathbf{3 9 . 1 9 \% )}\end{array}$ & $\begin{array}{l}\text { Morocco } \\
(\mathbf{3 5 . 5 2} \%)\end{array}$ & $\begin{array}{l}5,140 \\
(27.45 \%)\end{array}$ & $\begin{array}{l}\text { Ecuador } \\
(7.69 \%)\end{array}$ \\
\hline Castellón & 20.17 & 35,895 & 177,924 & $\begin{array}{l}3,781 \\
(10.53 \%)\end{array}$ & $\begin{array}{l}\text { Morocco } \\
(5.69 \%)\end{array}$ & $\begin{array}{l}4,927 \\
(13.71 \%)\end{array}$ & $\begin{array}{l}\text { Colombia } \\
(4.53 \%)\end{array}$ \\
\hline Girona & 19.69 & 18,610 & 94,484 & $\begin{array}{l}5,272 \\
(28.32 \%)\end{array}$ & $\begin{array}{l}\text { Morocco } \\
\text { (19.84) }\end{array}$ & $\begin{array}{l}7,328 \\
(39.37 \%)\end{array}$ & $\begin{array}{l}\text { Colombia } \\
(5.7 \%)\end{array}$ \\
\hline P. Mallorca & 19.49 & 77,330 & 396,570 & $\begin{array}{l}9,811 \\
(12.68 \%)\end{array}$ & $\begin{array}{l}\text { Morocco } \\
(4.39 \%)\end{array}$ & $\begin{array}{l}33,262 \\
(43.01 \%)\end{array}$ & $\begin{array}{l}\text { Ecuador } \\
(8.70 \%)\end{array}$ \\
\hline Lleida & 18.23 & 24,016 & 131,731 & $\begin{array}{l}9,299 \\
(38.72 \%)\end{array}$ & $\begin{array}{l}\text { Morocco } \\
(15.93 \%)\end{array}$ & $\begin{array}{l}5,726 \\
(23.84 \%)\end{array}$ & $\begin{array}{l}\text { Colombia } \\
(5.59 \%)\end{array}$ \\
\hline Madrid & 16.79 & 539,624 & $3.213,271$ & $\begin{array}{l}40,700 \\
(7.54 \%)\end{array}$ & $\begin{array}{l}\text { Morocco } \\
(4.65 \%)\end{array}$ & $\begin{array}{l}317,221 \\
(58.78 \%)\end{array}$ & $\begin{array}{l}\text { Ecuador } \\
(18.53 \%)\end{array}$ \\
\hline Tarragona & 16.54 & 22,768 & 137,536 & $\begin{array}{l}7,840 \\
(34.43 \%)\end{array}$ & $\begin{array}{l}\text { Morocco } \\
(26.19 \%)\end{array}$ & $\begin{array}{l}6,654 \\
(29.25 \%)\end{array}$ & $\begin{array}{l}\text { Colombia } \\
(9.56 \%)\end{array}$ \\
\hline Guadalajara & 14.53 & 11,807 & 81,221 & $\begin{array}{l}2,288 \\
(19.37 \%)\end{array}$ & $\begin{array}{l}\text { Morocco } \\
(14.52 \%)\end{array}$ & $\begin{array}{l}3,899 \\
(33.02 \%)\end{array}$ & $\begin{array}{l}\text { Ecuador } \\
(9.04)\end{array}$ \\
\hline Alicante & 14.44 & 47,915 & 331,750 & $\begin{array}{l}9,005 \\
(18.73 \%)\end{array}$ & $\begin{array}{l}\text { Morocco } \\
(0.07 \%)\end{array}$ & $\begin{array}{l}20,274 \\
(42.31 \%)\end{array}$ & $\begin{array}{l}\text { Colombia } \\
(10.68 \%)\end{array}$ \\
\hline Valencia & 14.15 & 114,260 & 807,200 & $\begin{array}{l}13,265 \\
(11.60 \%)\end{array}$ & $\begin{array}{l}\text { Morocco } \\
(2.70 \%)\end{array}$ & $\begin{array}{l}58,376 \\
(51.09 \%)\end{array}$ & $\begin{array}{l}\text { Ecuador } \\
(13.77 \%)\end{array}$ \\
\hline Logroño & 13.81 & 20,728 & 150,071 & $\begin{array}{l}3,460 \\
(16.69 \%)\end{array}$ & $\begin{array}{l}\text { Morocco } \\
(9.35 \%)\end{array}$ & $\begin{array}{l}6,492 \\
(31.31 \%)\end{array}$ & $\begin{array}{l}\text { Ecuador } \\
(7.69 \%)\end{array}$ \\
\hline
\end{tabular}

Source: Instituto Nacional de Estadistica (National Institute of Statistics). Propriety production.

3.4 This fact is of major importance if we observe how, in the majority of research on attitudes about immigration, it is the African groups that are more often rejected by the native population, especially those coming from the Maghreb (in most cases, Moroccans and, to a lesser extent, Algerians). Those that practice Islam meet with similar reactions.

3.5 On the other hand, if we group together Africans and South Americans as the stereotypical immigrants most identified by the Spanish population. Almería is second behind Girona (67.69\%) as the capital with the greatest percentage $(66.64 \%)$.

3.6 More particularly, the twenty census districts where the research will be focused had a total of 32,196 inhabitants registered as of January 1,2008, of which 26,598 were Spanish citizens and 5,595 were foreign (i.e., $17.38 \%$ ). The majority of the immigrants were from Africa (65.95\%), with Moroccans as the largest group (63.20\%).

Table 2. Spanish and foreigners in Almería by census district according to the 2008 Municipal Census. 


\begin{tabular}{|l|l|l|l|l|l|l|l|l|}
\hline $\begin{array}{l}\text { Census } \\
\text { District }\end{array}$ & $\begin{array}{l}\text { Total } \\
\text { Population }\end{array}$ & Spanish & $\begin{array}{l}\text { Total } \\
\text { Foreigners }\end{array}$ & $\begin{array}{l}\text { Total } \\
\text { Europe }\end{array}$ & $\begin{array}{l}\text { Total } \\
\text { Europe, } \\
\text { non-EU }\end{array}$ & $\begin{array}{l}\text { Total } \\
\text { Africa }\end{array}$ & Morocco & $\begin{array}{l}\text { Total } \\
\text { America }\end{array}$ \\
\hline 041308006 & 1253 & 1213 & 40 & 23 & 3 & 7 & 6 & 7 \\
\hline 041308003 & 1596 & 1300 & 296 & 170 & 6 & 113 & 107 & 4 \\
\hline 041307035 & 2143 & 1601 & 542 & 169 & 47 & 183 & 166 & 132 \\
\hline 041307028 & 1597 & 1543 & 54 & 19 & 0 & 2 & 2 & 30 \\
\hline 041307024 & 1356 & 1062 & 294 & 129 & 2 & 131 & 127 & 25 \\
\hline 041307015 & 2268 & 1840 & 428 & 165 & 17 & 95 & 82 & 132 \\
\hline 041306038 & 2050 & 1982 & 68 & 31 & 6 & 17 & 11 & 14 \\
\hline 041306034 & 1334 & 1292 & 42 & 9 & 8 & 0 & 0 & 14 \\
\hline 041306031 & 1862 & 765 & 1097 & 1 & 0 & 1096 & 1068 & 0 \\
\hline 041306024 & 1610 & 962 & 648 & 7 & 1 & 639 & 635 & 1 \\
\hline 041306023 & 1939 & 1089 & 850 & 7 & 2 & 839 & 834 & 2 \\
\hline 041306021 & 1825 & 1793 & 32 & 4 & 1 & 18 & 18 & 5 \\
\hline 041306005 & 1614 & 1559 & 55 & 6 & 2 & 0 & 0 & 28 \\
\hline 041305005 & 1819 & 1480 & 339 & 99 & 7 & 104 & 86 & 109 \\
\hline 041305004 & 1864 & 1504 & 360 & 46 & 9 & 137 & 92 & 163 \\
\hline 041304001 & 943 & 914 & 29 & 14 & 1 & 0 & 0 & 14 \\
\hline 041303003 & 1627 & 1308 & 319 & 19 & 1 & 286 & 279 & 11 \\
\hline 041302006 & 1340 & 1297 & 43 & 10 & 1 & 9 & 9 & 19 \\
\hline 041302005 & 1369 & 1332 & 35 & 14 & 4 & 6 & 6 & 11 \\
\hline 041302003 & 787 & 762 & 25 & 7 & 0 & 9 & 9 & 9 \\
\hline Total & 32,196 & 26,598 & 5,596 & 949 & 118 & 3,691 & 3,537 & 730 \\
\hline Source Prop & & & & & & \\
\hline
\end{tabular}

Source: Proprietary production

\section{Instrument}

\section{Indexes}

4.1 In this analysis, we will work with the xenophobia index, the materialism/postmaterialism index, the social position index, the family socioeconomic status index, and the State Foreign Policy index.

4.2 Our index of xenophobia is based on attitudes toward immigration which are related to density. These variables capture the rejection, prevention, and fear or ignorance towards foreign immigrants and more particularly towards certain groups such as Gypsies, Moroccans, North African-Americans, South Americans, and Eastern Europeans. The higher the density of immigrants in a certain area and the more that immigrants belong to certain nationalities or ethnic groups, the greater the possibility that the native population develops attitudes of rejection related to: 1. competition for scarce resources (labor and economic crisis circumstances $\left.{ }^{[4]}\right)$ 2. multicultural education, loss of cultural identity, intimate relationships and / or exogamy.

4.3 The questions used to construct the xenophobia index explored basic attitudes toward immigration. These attitudes have been measured using five agreement/disagreement statements that were presented to respondents: a) Workers from other countries should be admitted only when there are no Spanish citizens to fill those jobs; b) The economic situations in Spain is difficult enough without having to allot money to help immigrants; c) Whatever else is said, we would all mind if our children had classmates of other races in school; d) Immigration will eventually cause Spain to lose its identity; e) Citizens of any country should have the right to settle in any other country without any type of limitations. Those who responded that they "strongly agree" or "agree" with statements a), b), c) and d) or "strongly disagree" or "disagree" with statement e) were assigned one point. Similarly, a point was assigned to respondents who would prohibit their daughter from having relations with a man from each of the following social groups: gypsies, North Africans, black Africans, South Americans and Eastern Europeans. Finally, a point was also assigned to those who found it upsetting to live in a neighbourhood with South Americans, gypsies, black Africans or Moroccans.

4.4 The Materialism/Postmaterialism Index ranges from 1-3, where 1 indicates materialist values, 3 indicates postmaterialist values, and 2 indicates a mixture.

4.5 The Social Position Index is a synthetic index that combines eight different and dichotomised variables: sex, age, educational level, occupational status, monthly family income, sector of economic activity, size of residential habitat, and geographic centrality.

4.6 The Family Socioeconomic Status Index is based on family income, the occupation of the head of household and household amenities. Four levels have been defined combining these three indicators: high, medium, medium-low, and low. 
4.7 The State Foreign Policy index is built on a scale of 0-6 points based on positive responses to the following question: "Do you think the Spanish state should provide the following to immigrants: access to housing, unemployment benefits, health care, free children's education, free spousal education, immigrant unemployment benefits, courses in Spanish, or professional training courses?".

4.8 Finally, we have introduced five independent variables for the regression model: evaluation of state policies, ideology (radicalism), nationalism (radicalism), and two variables related with social services (housing and education for children, and healthcare). Evaluations of state policies are constructed on a scale of 0-6 points based on affirmative responses to the following question: "Do you think the Spanish state should provide the following aid to immigrants: access to housing, unemployment benefits, health care, free education for children, free education for spouses, unemployment benefits for emigrants [SIC], Spanish courses, vocational courses for immigrants. Ideology (radicalism) was constructed based on the political ideology wherein the centre has lesser value and the extreme right and the extreme left have greater value. Nationalist (radicalism) was constructed based on nationalism, where dual identification, the "as much Andalusian as Spanish" option, has a lesser value and the pro-Spain and nationalist options, i.e., "only Spanish" and "only Andalusian", have a greater value. The two variables related with the social service were based on basic social services such as housing, and education for children and healthcare. Because of the dichotomous response options (yes or no), two new ordinal variables were created, called legal and illegal, from 0 to 7 , where zero meant no services were offered and 7 meant all services were offered.

\section{Procedure}

4.9 Selection of census districts. The native population over 18 that comprises the sampling framework consists only of those residing in Almería census districts with a high or low number of foreigners. We followed the approach in which, of 121 city districts, only the 10 districts each with the highest and lowest numbers of foreigners were selected.

4.10 Samples and Error. The sample was made up of 602 subjects over 18 of either sex, each living in one of the twenty census districts with the highest and lowest receipt of foreigners. Multistage sampling was employed, with the last stage using random routes and simple affixation by district and proportional by sex and age. The confidence level was $95 \%(p=q=0.50)$, and the assumed sampling error was $4 \%$. The fieldwork was conducted in May 2009.

\section{Analysis of the results:}

\section{Census districts and the xenophobia index}

5.1 The twenty census districts, the 10 with high immigrant density and the 10 with low immigrant density, as shown in the attached table, vary from $58.9 \%$ foreigners to $1.8 \%$.

Table 3. Almería census districts and the xenophobia index

\begin{tabular}{|l|l|l|l|l|l|} 
Section & \multicolumn{1}{l}{ Population } & \multicolumn{1}{l}{ Foreigners } & \multicolumn{2}{l}{ District } & \multicolumn{2}{l|}{ Xenophobia } \\
\hline 0401307035 & 2,143 & 542 & $25.3 \%$ & Zapillo - Antonio Atienza & 4.73 \\
\hline 0401308006 & 1,253 & 40 & $3.2 \%$ & Cueva de las Medinas & 4.37 \\
\hline 0401306024 & 1,610 & 648 & $40.2 \%$ & Puche - Malagueñas & 4.27 \\
\hline 0401306023 & 1,939 & 850 & $43.8 \%$ & Puche - Taranto & 4.07 \\
\hline 0401305004 & 1,864 & 360 & $19.3 \%$ & Cabo de Gata & 3.90 \\
\hline 0401306005 & 1,614 & 55 & $3.4 \%$ & Diezmo & 3.70 \\
\hline 0401307024 & 1,356 & 294 & $21.7 \%$ & Venta Gaspar & 3.67 \\
\hline 0401306038 & 2,050 & 68 & $3.3 \%$ & Costa de Almería & 3.60 \\
\hline 0401302006 & 1,340 & 43 & $3.2 \%$ & Almería - Virgen del Mar & 3.13 \\
\hline 0401303003 & 1,627 & 319 & $19.6 \%$ & Almería - Las Pedrizas & 3.13 \\
\hline 0401306021 & 1,825 & 32 & $1.8 \%$ & Los Almendros -Traviata & 3.03 \\
\hline 0401307028 & 1,597 & 54 & $3.4 \%$ & Centro - Altamira & 2.97 \\
\hline 0401304001 & 943 & 29 & $3.1 \%$ & Rambla Belén & 2.97 \\
\hline 0401306031 & 1,862 & 1,097 & $58.9 \%$ & Puche - Mare Nostrum & 2.77 \\
\hline 0401305005 & 1,819 & 339 & $18.6 \%$ & Quemadero & 2.50 \\
\hline 0401306034 & 1,334 & 42 & $3.1 \%$ & $\begin{array}{l}\text { Puche - Barrilero Lomas de } \\
\text { Acosta }\end{array}$ & 2.50 \\
\hline 0401307015 & 2,268 & 428 & $18.9 \%$ & Almería - Zapillo & 2.37 \\
\hline 0401308003 & 1,596 & 296 & $18.5 \%$ & Cabo de Gata & 2.27 \\
\hline 0401302003 & 787 & 25 & $3.2 \%$ & Paseo de Almeria - Virgen de la & \\
\hline 0401302005 & 1,367 & 35 & $2.6 \%$ & Centre & 2.23 \\
\hline
\end{tabular}

5.2 Of the twenty districts, only two fail to corroborate the baseline hypothesis: the district containing the Cuevas de la Medina neighbourhood, which has a foreign population of $3.2 \%$ and a xenophobia index of 
4.37, and on the opposite side, the Puche-Mare Nostrum neighbourhood, with $58.9 \%$ foreigners and a xenophobia index of only 2.77. In the remaining districts, greater or lesser immigrant density means a higher or lower xenophobia index in Almería.

5.3 This variation in the trend may be explained by various factors at play in both neighbourhoods. In the case of the Cuevas de la Medina neighbourhood, we should consider two variables: social position index and education. The observed trend is that the lower the social position of the community, the higher the xenophobia index and vice versa. Additionally, the higher the level of education, the smaller the tendency to exhibit xenophobic attitudes or behaviours. In the Cuevas de la Medina neighbourhood, $60 \%$ of the residents occupy a low social position, while 33.3\% occupy a middle-class social position and $6.7 \%$ enjoy a high-level social position. With respect to educational level, we can note that nearly three-quarters of the residents in that neighbourhood (73.3\%) fell in the range between failing to complete primary school education and receiving a diploma equivalent.

5.4 In the El Puche-Mare Nostrum neighbourhood, there is no logical explanation for our findings based on the variables used, and if we note that $86.7 \%$ indicated that they were not considering changing neighbourhoods in the near future while $80 \%$ did not have an answer regarding their hopes for the population composition of the neighbourhood in which they would want to live. While this is a marginal neighbourhood, this puzzle may also be explained by investments made both by the Spanish government through the Ministry of Labour and Immigration and the regional government of Andalusia in neighbourhoods whose immigrant populations exceed $30 \%$ and which have "strong immigration pressure, an elevated rate of truancy and unemployment, a disruption of the social fabric, and a low socioeconomic level." According to the newspaper Ideal (2010: 8), the neighbourhood of Puche received 1.3 million Euros in funding in 2009 and 2010 for programs related to socio-educational intervention, the promotion of multiculturalism, training and employment, information and awareness, and the provision of guidance and advice to residents. We must conclude that this contradiction is due to this and other intervening factors and should be the object of a specific study.

$\mathbf{5 . 5}$ In the past, until a decade ago, it was inhabited by gypsies, and the majority of its inhabitants are now immigrants from Morocco (see Table 1). On the other hand, if we consider the xenophobia index in the census districts with high immigrant density (more than $21 \%$ foreigners) and very low immigrant density (less that 3.2\% foreigners), we note that the former exhibit an average xenophobia score of 3.90, while the latter display an average score of 2.43: i.e., there exists a difference of 1.47 between them.

Table 4. Xenophobia index in census districts (2009) of the city of Almería with high and low immigrant densities.

\begin{tabular}{|c|c|c|}
\hline & $\begin{array}{l}\text { Very high } \\
(>21 \%)\end{array}$ & $\begin{array}{l}\text { Very low } \\
(<3.2 \%)\end{array}$ \\
\hline & $\%$ & $\%$ \\
\hline 0 Not at all & & \\
\hline xenophobic & 2.7 & 20.7 \\
\hline 1 & 12.0 & 21.3 \\
\hline 2 & 12.0 & 11.3 \\
\hline 3 & 18.7 & 19.3 \\
\hline 4 & 26.0 & 15.3 \\
\hline 5 & 9.3 & 4.7 \\
\hline 6 & 5.3 & 2.7 \\
\hline 7 & 4.7 & 1.3 \\
\hline 8 & 4.7 & 0.7 \\
\hline 9 & 2.0 & 2.0 \\
\hline 10 & 2.0 & \\
\hline 11 & 0.7 & 0.7 \\
\hline 12 & 0.0 & 0.0 \\
\hline 13 & 0.0 & 0.0 \\
\hline 14 Very xenophobic & 0.0 & 0.0 \\
\hline Average xenophobia & 3.90 & 2.43 \\
\hline Standard deviation & 2.28 & 2.15 \\
\hline
\end{tabular}

\section{Describing xenophobia}

5.6 The xenophobia index in the city of Almería is 3.2, which is slightly lower than in the score for those of Almería's municipalities with high immigrant density (3.7) (See Herranz, 2008). The index is also almost a point higher than the Spanish average in 2003, which was 2.5 (e. g. Diez, 2005:92). We can conclude by confirming our baseline hypothesis that high immigrant density encourages xenophobic behaviours and attitudes both in municipal neighbourhoods and in the city of Almería as a whole. 
5.7 Nevertheless, this reduction in the xenophobia index compared to the results of the previous study may be partly the result of attitudinal, economic and socio-psychological factors. The attitudes of those in Almería who remain in neighbourhoods with high immigrant density must be based on internalisation, assimilation and acceptance of the present and, consequently, on coexistence with immigrants.

Economic explanations for this phenomenon emphasise the economic limitations on resident migration to other areas, as demonstrated in several qualitative studies, or underline the ethno-cultural characteristics of the residents as a factor. Socio-psychological explanations, on the other hand, are based on general negative stereotypes that change when immigrants who become well-known neighbours. The attitudes of rejection displayed by neighbourhood residents exposed to high immigrant density are directed, as has been clearly shown in qualitative studies, "toward those foreigners that are known to live or spend their time in their neighbourhood, but whom they do not know individually". That is to say, "more abstract forms of rejection coexist, within the Spanish citizens' discourse, alongside the acceptance of specific individuals whom they known personally". This was one of the explanations given in comparing xenophobia in municipalities and in the neighbourhoods in Almería with high immigrant density. Indeed, while the xenophobia index in the municipalities was 5.3, in the neighbourhoods it was 3.7, presenting a difference of 1.6 points (Herranz, 2008a: 118-119).

Table 5. Xenophobia index in Almería (2006 and 2009)

\begin{tabular}{|c|c|c|}
\hline & Almería '06 & Almería '09 \\
\hline & $\%$ & $\%$ \\
\hline $\begin{array}{l}0 \text { Not at all } \\
\text { xenophobic }\end{array}$ & 11.7 & 11.6 \\
\hline$\overline{1}$ & 14.7 & 15.9 \\
\hline 2 & 13.1 & 15.3 \\
\hline 3 & 12.2 & 19.6 \\
\hline 4 & 15.0 & 15.9 \\
\hline 5 & 10.6 & 6.1 \\
\hline 6 & 7.1 & 5.3 \\
\hline 7 & 5.4 & 3.0 \\
\hline 8 & 3.8 & 2.8 \\
\hline 9 & 3.6 & 2.2 \\
\hline 10 & 0.7 & 1.0 \\
\hline 11 & 0.8 & 0.8 \\
\hline 12 & 0.5 & 0.3 \\
\hline 13 & 0.7 & 0.0 \\
\hline 14 Very xenophobic & 0.1 & 0.0 \\
\hline Average xenophobia & 3.7 & 3.2 \\
\hline Standard deviation & 2.9 & 2.4 \\
\hline
\end{tabular}

5.8 Additionally, for the sake of comparison, where $39.2 \%$ are not xenophobic in Almería's municipal neighbourhoods, the percentage in the city of Almería is $42.8 \%$. Correspondingly, those who were somewhat or very xenophobic comprised $59.9 \%$ in the municipality's neighbourhoods, while in the capital, this percentage was slightly less, $(57.1 \%)$. One should keep in mind here that slightly more than one-fifth $(22.4 \%)$ of individuals in Almería's municipal neighbourhoods may be considered very xenophobic, while in the capital, this figure is $10.1 \%$. In both environments, the majority of individuals fall into the "somewhat xenophobic" category.

5.9 Comparing the data at both levels of analysis, we can conclude that there exist moderately high indices of xenophobia in Almería, whether at the neighbourhood level or in the capital city. Regarding the socioeconomic profile of those individuals in Almeria who can be considered more or less xenophobic, the data indicate a great deal of similarity, although there do exist some differences.

$\mathbf{5 . 1 0}$ In the capital city of Almería and the municipal neighbourhoods, the profiles of the most xenophobic residents match up, especially with respect to the individuals' higher age, low level of education, and low social position. Additionally, they perceive themselves as belonging to a low social class (except in the case of the capital city, where they perceive themselves as belonging to the upper class), they are ideologically Right-ist (but Centrist in the capital city), they are nationalist but also pro-Spain in the neighbourhoods, and they are materialist and do not travel abroad. The least xenophobic in Almería also match up in terms of their socioeconomic profile in most cases, especially with respect to their lower age, high level of education, high social position, and Leftist political beliefs (although in the capital city some are Rightists); they also exhibit a dualist nationalist identification and supra-national identification and tend to travel abroad.

\section{Explaining xenophobia}

5.11 Moving forward with the research, we conducted a multiple regression analysis to observe the 
different variables that seem to best explain the xenophobia index. First, before working with the regression models, we were interested in knowing the degree and sign of the association between the xenophobia index and the most significant demographic variables. In the 2006 research on municipal neighbourhoods in Almería, we found that those variables that have a greater level of association with xenophobia are education, materialism/postmaterialism, income, geographical identity, age, social class and ideology. The criteria are the following: ideology (low toward the left and high toward the right), geographic identification (low indicates localist identification and high indicates universalist), nationalism (low indicates nationalist sentiment and identification and high indicates that one is more pro-Spain) and postmaterialism (low indicates a more materialist position and high indicates a more postmateralist one). For the capital city of Almería, those with the greatest level of association are level of education, income, ideology, geographical identity and social position.

$\mathbf{5 . 1 2}$ In the first model, the independent variables included coincide with those used to describe the profile of the interviewees under the xenophobia index.

Table 6. Regression Analysis of diverse Socio-demographic Indicators (independent variables) on the Xenophobia Index (dependent variable)

\begin{tabular}{|lll|}
\hline Almería & Almería 2009 & Almería 2006 \\
\hline $\begin{array}{l}\text { Multiple Correlation } 0.41 \\
\text { Coefficient R= }\end{array}$ & 0.42 \\
\hline $\begin{array}{l}\text { Standardised } \\
\text { Regression Coefficients } \\
\beta:\end{array}$ & 3.465 & \\
\hline Educational Level & -.277 & -.395 \\
\hline $\begin{array}{l}\text { Ideology (degree } \\
\text { Rightist) }\end{array}$ & .619 & \\
\hline Social Position & .085 & .317 \\
\hline Postmaterialism & -.167 & -.700 \\
\hline Spatial Identification & -.072 & -.049 \\
\hline Nationalism & -.017 & .126 \\
\hline Family Income & .359 & -.426 \\
\hline Age & .145 & -.008 \\
\hline & & \\
\hline
\end{tabular}

Source: Almería. Proprietary production.

5.13 The correlation coefficient was 0.41 for the capital city of Almería, and 0.42 for the municipal neighbourhoods, so the socio-demographic and socio-political variables in both cases display acceptable explanatory power regarding the variation of the degree of xenophobia.

5.14 According to this data, we can say that in the capital city of Almería and in the municipal neighbourhoods with high immigrant density, there are certain mutual trends that both models display: 1 . The more individuals favour a postmaterialist position, the less xenophobic they are. 2. The lesser the family income, the greater the tendency toward xenophobic behaviours and attitudes. 3 . Education is also a reference point, with individuals who display low education levels tending toward more xenophobic attitudes - this behaviour decreases with higher educational levels. 4. With respect to political ideology, the more leftward individuals position themselves, the less xenophobia they display, and this tendency is inverted as individuals situate themselves further to the right.

5.15 Among those variables that were not statistically predictive, in the capital city of Almería, the younger the residents are, the less xenophobia they tend to display. The tendency toward xenophobia tends to increase as we age. For individuals living in high-density municipal neighbourhoods in Almeria, the higher the social position, the greater the degree of xenophobia. Finally, nationalist identification in the municipal neighbourhoods of Almería shows a positive relationship with xenophobia, with the latter manifesting to a higher degree along with the former.

5.16 The second model introduces the index of xenophobia as an independent variable and a possible predictor of attitudes regarding different immigration-related issues. The independent variables included were education level; ideology; social position; nationalism; willingness to rent housing to South Americans, gypsies, etc. as well as the xenophobia index. The dependent variables were employed as keys to understanding attitudes toward immigrants on the part of Almería's residents: attitudes regarding policies towards immigrants favouring integration or return, the impact of immigration on unemployment, the impact of immigration on wages, the impact of immigration on crime; the state's provision of unemployment benefits to immigrants, and finally, whether the children of illegal immigrants should be provided with public education.

Table 7. Multiple Correlation Coefficients of a set of independent variables 1 for each of six Attitudes toward Immigration and standardised regression coefficients of the Xenophobia Index for each of these six Attitudes. 


\begin{tabular}{|lllll|}
\hline & $\begin{array}{l}\text { Almería } \\
2009\end{array}$ & & Almería 2006 \\
\hline & $\mathrm{R}$ & $\beta$ Xen & $\mathrm{R}$ & $\beta$ Xen \\
\hline Integration vs. Return & 0.20 & -0.00 & 0.22 & 0.15 \\
\hline Impact on Unemployment & 0.23 & -0.08 & 0.17 & -0.04 \\
\hline Impact on Wages & 0.20 & -0.09 & 0.17 & -0.05 \\
\hline Impact on Crime & 0.27 & -0.03 & 0.15 & -0.09 \\
\hline Unemployment Benefits & 0.33 & 0.03 & 0.38 & -0.26 \\
\hline $\begin{array}{l}\text { School for Children of Illegal } \\
\text { Immigrants }\end{array}$ & 0.40 & 0.05 & 0.14 & 0.04 \\
\hline
\end{tabular}

Source: Proprietary production.

$\mathbf{5 . 1 7}$ In the capital city of Almería, we see that the most significant multiple correlation coefficients, and, therefore, those that can be considered explanatory and predictive variables for attitudes toward immigration on the part of Almeria's citizens residing in these census districts, correspond to attitudes about unemployment benefits and the status of illegal immigrants' children. In the case of the municipal neighbourhoods, unemployment benefits are a particularly good predictor.

5.18 Both in the capital and in the municipal neighbourhoods, the model seems to best explain attitudes toward immigration using the unemployment benefits variable. Additionally, in the capital, expectations regarding the possibility that the state will provide free education for the children of illegal immigrants in public schools are also highly predictive of xenophobia.

5.19 However, the variables "effects on crime and unemployment" report that the greater the xenophobic attitudes of the population of the capital (Almeria), the more the immigrants are perceived as a threat that increases unemployment and crime. In the neighborhoods, the xenophobic population is more in favour of the return of immigrants and less in their integration.

$\mathbf{5 . 2 0}$ In short, the models for the capital and the municipal neighbourhoods show the high explanatory power of the set of selected variables with respect to the distinct attitudes of Almeria's residents toward immigration. These variables explain 33\% and 38\% (in the case of unemployment benefits) and $40 \%$ (in the case of free education for the children of illegal immigrants at the municipal level).

5.21 A third model has been included to examine the behaviour of the xenophobia index using a series of extreme values for a group of three exclusively sociopolitical-cultural variables.

5.22 The three independent variables included in the regression model were opinions regarding state policy, ideology and nationalism (radicalism). The correlation coefficient, both in the capital and in the municipal neighbourhoods, is also quite high compared to the previous models, and the xenophobia index seems to be explained by variables already seen in other models such as age, the postmaterialism index, and the education level (especially in neighborhoods with high immigration density). Religious practice or nationalism in the capital is not a good predictor.

5.23 With regard to the latter three, we can make several observations. The explanatory power of opinions regarding state policies shows the same behaviour in the capital city as in the municipal neighbourhoods of Almería. In the municipal neighbourhoods, these values have a negative sign and indicate that the more in favour the citizens are of state policies benefiting immigrants (access to housing, health care, etc.), the less xenophobic they are. In the capital, however, the opposite occurs. Ideological radicalism has a direct relationship with the xenophobia index in the sense that the more radical ideological positions are, the higher the xenophobia index is. Radical nationalism is directly related to the degree of xenophobia only in the municipal neighbourhoods, not in the capital city: the greater the individual's identification with nationalist sentiments, including pro-Spain sentiments, the greater the likelihood that this individual displays xenophobic behaviours and attitudes towards foreigners.

$\mathbf{5 . 2 4}$ In short, more radical positions, together with other variables, also seem to explain and predict xenophobia in Almería, as in municipal neighbourhoods with high immigrant density.

Table 8. Regression Analysis of different sociopolitical-cultural variables (independent variables) on the Xenophobia Index (dependent variable) 


\begin{tabular}{|lll|}
\hline & Almería 2009 & Almería 2006 \\
\hline Multiple Correlation Coefficient R= & 0.44 & 0.45 \\
\hline Standardised Regression Coefficients $\beta:$ & -.970 & .509 \\
\hline State (policies) & .431 & -.319 \\
\hline Educational Level & -.086 & -.215 \\
\hline Postmaterialism & -.511 & -.700 \\
\hline Religious Practice & -.029 & -.009 \\
\hline Ideology (radicalism) & .171 & .555 \\
\hline Nationalism (radicalism) & -.007 & .421 \\
\hline Age & .385 & .451 \\
\hline
\end{tabular}

Source: Proprietary production.

A fourth model attempts to analyse the endlessly controversial issue of legal and illegal immigration. Toward this end, two variables have been created that relate to service offerings that the Spanish welfare state provides to immigrants, both legal and illegal.

5.25 Following the correlation analysis, xenophobia has a greater level of association with the variables that represent attitudes toward state policies regarding legal and illegal immigrants, education level, social position, geographical identity and age. In this sense, the trend exhibited in the previous models continues for all variables in terms of both sign and association. In particular, the more xenophobic Almería residents living in both high and low immigrant density neighbourhoods are, the less in favour they are of state-provided social benefits for immigrants.

$\mathbf{5 . 2 6}$ In this model, the correlation coefficient was 0.50 , indicating that the socio-demographic and sociopolitical variables have high explanatory power with respect to variation in the degree of xenophobia. In addition, the most significant predictors were education and the perception of social rights for legal immigrants.

Table 9. Regression analysis of different socioeconomic variables and legal and illegal immigrant status (independent variables) on the Xenophobia Index (dependent variable)

\begin{tabular}{|ll|}
\hline Almería & Almería 2009 \\
\hline $\begin{array}{l}\text { Multiple Correlation } \\
\text { Coefficient R= }\end{array}$ \\
\hline $\begin{array}{l}\text { Standardised } \\
\text { Regression Coefficients } \\
\beta:\end{array}$ \\
\hline Social Position Index & -.060 \\
\hline Age & .043 \\
\hline Education & -.139 \\
\hline Geographical Identity & -.089 \\
\hline Ideology & -.042 \\
\hline Nationalism & .035 \\
\hline Illegal Immigrants & -.080 \\
\hline Legal Immigrants & -.105 \\
\hline
\end{tabular}

Source: Proprietary production

5.27 According to these data, education level continues to be a reference point that explains xenophobia, where greater xenophobic attitudes are observed among individuals with low education levels. With regard to legal immigrants, the more xenophobic one is in the capital city of Almería, the less willing one is to support the state's providing immigrants with certain social services, such as access to housing, healthcare, and free education for children.

5.28 Finally, a model has been included that analyses the thoughts or beliefs of the population of Almería about certain immigration-related issues, principally those related to whether immigrants should be excluded from the workforce or whether immigration should be restricted overall based on the competition for scarce resources or cultural identity. Recoding the categories strongly agree/agree and

disagree/strongly disagree, the percentages were as follows: Admission of workers: $67.5 \%$ versus $32.5 \%$; Difficulty of economic situation: $57.3 \%$ versus $42.7 \%$; Immigrant children in schools would be bothersome: $11.8 \%$ versus $88.2 \%$; Immigration and identity loss: $42.5 \%$ versus $57.5 \%$, and Right to free immigration; $40.9 \%$ versus $59.1 \%$.

5.29 If we check the correlations, we see that all of the issues raised in connection with immigration have an elevated association with the xenophobia index. This is especially true for the issues of whether the admission of foreigner workers should be limited based on internal demand and whether immigrant aid should be reconsidered in economic crisis situations. 
Table 10. Regression analysis of different aspects of immigration (independent variables) on the xenophobia index (dependent variable)

\begin{tabular}{|ll|}
\hline & Almería 2009 \\
\hline Multiple Correlation Coefficient R= & 0.76 \\
\hline Standardised Regression Coefficients $\beta$ : & \\
\hline $\begin{array}{l}\text { Admission of workers to cover positions unwanted by Spanish } \\
\text { citizens }\end{array}$ & -.265 \\
\hline Economic situation difficulty and helping immigrants & -.254 \\
\hline Immigrant children in schools would be bothersome & -.167 \\
\hline Immigration and the loss of Spain's identity & -.185 \\
\hline Right to free immigration in any country & .251 \\
\hline
\end{tabular}

Source: Proprietary production.

5.30 Of all the models, this has the highest correlation coefficient (0.76). This indicates that perceptions related to certain immigration-related issues have high explanatory power with regard to the variation of the degree of xenophobia. Additionally, the most significant predictors were agreement that immigrants should only be admitted as workers when there are no Spanish citizens available to fill positions and denial of immigrant aid when the economic climate is unfavourable (e.g. Solé, Parella, Alarcon, Bergalli, Gibert, 2000; Vallés, Cea, Izquierdo, 1999), in addition to the right to emigrate to any country with any hindrances. The variables 'children of immigrant would be bothersome in schools' and 'contributes to the loss of Spanish identity" have a lower explanatory power.

5.31 On this basis, it is possible to conclude that the more xenophobic residents of Almería agree that immigrants should work only when positions cannot be filled by Spanish citizens and that immigrants should be denied aid in times of economic difficulty. In the same way, the more xenophobic they are, the less likely they are to they support the right to free immigration from different countries without any limitations.

\section{Conclusions}

6.1 First, it has again become clear that from a methodological perspective, it is necessary to conduct segmented studies on immigration because of the uneven geographic distribution of immigrants. This step is essential to the analysis of xenophobia based on immigration density.

6.2 Additionally, the baseline hypothesis has been verified: immigrant density encourages xenophobic behaviours and attitudes within the population, in this case among the residents of the capital city of Almería who live in neighbourhoods with high immigrant density (over $21 \%$ ), as well as the differentiation (segmentation) of xenophobia according to place of origin.

6.3 What is more, of the twenty census districts analysed, only two were inconsistent with the baseline hypothesis. In the case of Cuevas de los Medinas, this inconsistency can be understood as a result of the socio-demographic characteristics of the neighborhood, with a high percentage of individuals displaying low social position and educational levels. This statement must be qualified. In the xenophobia study in Almería (Herranz, 2008:125), cited above, individuals with low and medium-level social positions were also among the most xenophobic. In fact, in the analysis of Almería neighbourhoods with high immigrant density using regression models, social position had a positive correlation with xenophobia; i.e., the greater the social position, the greater was the degree of xenophobia. On the other hand, in the Spanish case, this variable always shows the same trend: the lower the social position, the higher the degree of xenophobia, and vice versa. In the comparative study of Andalusia and Catalonia, it was observed that in Andalusia, those with a medium-level social position tended toward greater xenophobia, unlike in Catalonia (Herranz, 2010).

6.4 However, with regard to the second outlier (Puche Mare-Nostrum), we are not able to provide a logical explanation for the results based on the variables used, although our findings could be caused by the population structure, with many neighbourhoods populated by marginalised gypsy residents. It may also be a consequence of the Spanish and Andalusian governments' economic intervention schemes: in particular, their socio-educational policies, encouragement of multiculturalism and awareness, and provision of information and guidance related to the immigrant population.

6.5 Finally, in the five models used, the correlation coefficients were acceptably high, indicating that the factors examined display sufficient explanatory power regarding the variation in the degree of xenophobia, especially with respect to thoughts or beliefs about certain immigration-related issues, with $76 \%$ of the variation explained. In particular, there is a correlation between xenophobia and beliefs regarding the exclusion of immigrants from competition for scarce resources (labour resources, and resources more generally under circumstances of economic crisis) and the right to free immigration without governmental hindrance.

\section{Notes}

1 Obviously, fear and rejection of foreigners was manifested not only towards ethno-cultural groups undergoing the process immigration but also, for example toward tourists in a phenomenon that (Bauman, 2006) calls mixophobia, i.e., fear and rejection of the unknown and of cultural diversity in general. The opposite inclination is mixophilia, a state in which cultural diversity is interpreted as a source of 
enrichment, whether cultural, social or economic.

2 In general terms and not only with respect to density, there are studies that insist on this need (Portes, Rumbaut, 1996; Zhou, 1997).

3 (Cea, 2004:IX) also considers the intensification of the presence of immigrants as creating a "feeling of alarm in the native population, in which arises perceptions of an 'avalanche' or psychotic states of 'invasion'," the fear of a loss of national and cultural identity, and the desire to avoid the adulteration of previously achieved socioeconomic and legal accomplishments.

4 The following is some data describing the general economic circumstances. The unemployment rate in 2009 was 18.01\% in Spain, 25.35\% in Andalusia and 30.64\% in Almería while the EU average was 8.9\%. According to Eurostat data for 2007, the percentage of foreigners was $5.83 \%$ in Europe, $8.81 \%$ in Germany, and $10.35 \%$ in Spain. According to the National Immigrant Survey of 2007 from the INE (National Statistics Institute), 83.9\% of immigrants arrived in Spain without a work contract. Finally, in Spain, the perception of the main problems facing the country according to the CIS (Center for Sociological Research) Opinion Barometer in December 2009, were unemployment (78.9\%), economic problems (47\%), ETA terrorism (12.9\%), and immigration (12.4\%).

\section{References}

AGUINAGA, R.J. (2006). Racism and xenophobia in Spain: A pending reflections, Sistema, 190-191, 327346.

BAKER, M. (1981). The New Racism. London: Junction Books.

BAUMAN, Z. (2006). Confianza y temor en la ciudad. Vivir con extranjeros. Barcelona: Arcadia/Atmarcadia.

BLUMER, H. (1958). Race prejudice as a sense of group position. Pacific Sociological Review, 1, 3-7.

CALVO, T. (2000): Inmigración y racismo. Así se sienten los jóvenes del siglo XXI. Madrid, Cauce Editorial.

CEA D’ANCONA, M.A. (2004). La activación de la xenofobia en España. Madrid: CIS.

CEA D’ANCONA, M.A. (2002). La medición de las actitudes ante la inmigración: evaluación de los indicadores tradicionales de racismo. Revista Española Investigaciones Sociológicas, 99, 87-111.

CEA D’ANCONA, M.A. (2005). La exteriorización de la xenofobia. Revista Española Investigaciones Sociológicas, 112, 197-230.

CEA D’ANCONA, M.A. (2009). La compleja detección del racismo y la xenofobia a través de las encuestas. Un paso adelante en su medición. Revista Española Investigaciones Sociológicas, 125, 13-45.

CEA D’ANCONA, M M A. \& VALLÉS, M.S. (2008). Evolución del racismo y la xenofobia en España. Madrid: Ministerio de Trabajo e Inmigración.

DE LUCAS, J. (1992). Europa: ¿Convivir con la diferencia? Racismo, nacionalismo y derechos de las minorías. Madrid: Técnos.

Diario Ideal (2010). 11:Mayo.p.8.

DIEZ NICOLÁS, J. (1998). Actitudes hacia los inmigrantes. Madrid: Ministerio de Trabajo y Asuntos Sociales, Dirección General del Instituto de Migraciones y Servicios Sociales.

DIEZ NICOLÁS, J. (2005). Las dos caras de la inmigración. Madrid: Ministerio de Trabajo y Asuntos Sociales.

DIEZ NICOLÁS, J. (2009). La construcción de un índice de xenofobia y racismo. Revista del Ministerio del Trabajo y Asuntos Sociales, 80, 21-38.

ESCANDELL, X. \& CEOBAUNU, A. (2009). When contact with immigrants matters: threat interetnia attitudes and foreing exclusionism in Spain's Autonomous Community. Ethnic and Racial Studies, 32, 1, 44-69.

GIMENO, L. (2001). Actitudes hacia la inmigración. Relación entre las investigaciones cualitativas y cuantitativas, Colección Opiniones y actitudes, 34, Centro de Investigaciones Sociológicas, Madrid.

GONZALEZ ENRIQUEZ, C. (2004). Opinión pública y política de inmigración: elementos de conflicto en la convivencia con los inmigrantes en España. Madrid: Departamento de Ciencias Políticas y de la Administración, UNED, CPA Estudios, Working Papers.

HARGREAVES, A. G. \& LEAMAN, J. (1995). Racism in contemporary Western Europe: an overview. In Hargreaves, A. G. \& Leaman, J., (edits.) Racism, ethnicity and politics in contemporary Europe (pp.3-30). Aldershot Hants (England): Edward Elgar Publishing Limited.

HERRANZ DE RAFAEL, G. (2002). La xenofobia en Andalucía y Cataluña: un análisis comparativo. In La sociedad. Teoría e investigación (pp.175-205). Madrid: CIS. 
HERRANZ DE RAFAEL, G (2008). Xenofobia y multiculturalidad. Valencia: Tirant lo Blanch.

HERRANZ DE RAFAEL, G (2008a). Xenofobia: un estudio comparativo en barrios y municipios almerienses. REIS ,121, 107-132.

HERRANZ DE RAFAEL, G (2010). Modernidad y xenofobia en Andalucía y Cataluña: un análisis comparativo. Papers, 95-4, pp.977-1000.

LEONG, C. (2008). A multinivel research framework for the analyses of attitudes toward immigration, International Journal Intercultural Relations, 32 (2), 115-129.

[doi:://dx.doi.org/10.1016/j.ijintrel.2007.10.002]

MINISTERIO DE TRABAJO E INMIGRACIÓN (2008). Imágenes y experiencia del racismo en adolescentes y jóvenes. Madrid: Ministerio de Trabajo e Inmigración.

OPAM (2009). La evolución de las actitudes de los andaluces ante la inmigración en 2009: Una exploración cualitativa. Observatorio Permanente Andaluz de las Migraciones, №-1, Noviembre.

PÉREZ YRUELA, M. \& DESRUES, T. (2005). Opinión de los españoles en materia de racismo y xenofobia: Madrid, Ministerio de trabajo y Asuntos Sociales, Observatorio Español del Racismo y la Xenofobia.

PORTES, A. \& RUMBAUT, R. (1996). Inmigrant in American. California: University of California Press.

QUILLIAN, L. (1995). Prejudice as a response to perceived group threat: population composition and antiimmigrant and racial prejudice in Europe. American Sociological Review, 60, 586-611. [doi:://dx.doi.org/10.2307/2096296]

RINKEN, S., SILVA, M., VELASCO, S. \& ESCOBAR, M.S. (2009). Opiniones y actitudes de la población andaluza ante la inmigración II. Sevilla: Junta de Andalucía.

SNIDERMAN, P. M., HAGENDOORN, L. \& PRIOR, M. (2004). Predisposing factors and situational triggers: exclusionary reactions to immigrant minorities. American Political Science Review, 98, 1, $23-56$. [doi:://dx.doi.org/10.1017/S000305540400098X]

SOLÉ, C. (1995). Racial discrimination against foreigners Spain. New Community, 21(1), 95-101.

SOlÉ, C., ALARCÓN, A., GUBERT, F., PARELLA, S. \& RIBAS, N. (2001). El impacto de la inmigración en los países del sur de Europa. El caso de Grecia, Italia y Portugal. In Solé, C. (comp.) Elimpacto de la inmigración en la economía y en la sociedad receptora (pp. 249-277). Barcelona:Anthropos.

SOlÉ, C., PARELLA, S., ALARCÓN, A., BERGALLI, V. \& GILBERT, F. (2000). El impacto de la inmigración en la sociedad receptora. Revista Española de Investigaciones Sociológicas, 90, 131-157.

VALLÉS, M.S.; Cea, M.A. \& Izquierdo, A. (1999). Las encuestas sobre inmigración en España y Europa. Madrid: IMSERSO, Observatorio Permanente de la Inmigración, №-3.

VAN DIJK, T. A. (1987). Communicating racism. Ethnic prejudice in thought and talk. Newbury Park. California: Sage.

ZHOU, M. (2003) Segmented assimilations: issues, controversias and recent research on the new second generation. International Migration Review, 31(4), 975-1008. [doi:://dx.doi.org/10.2307/2547421] 